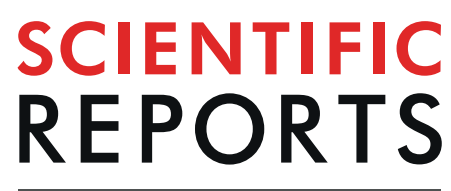

natureresearch

\title{
Chaperone Sigma1R mediates the neuroprotective action of afobazole in the 6-OHDA model of Parkinson's disease
}

\begin{abstract}
Mikhail V. Voronin $\mathbb{1}^{1}$, Ilya A. Kadnikov $\mathbb{1}^{1 *}$, Dmitry N. Voronkov $\mathbb{D}^{2}$ \& Sergey B. Seredenin ${ }^{1}$
Parkinson's disease (PD) is a progressive neurodegenerative disease with limited treatment options. Therefore, the identification of therapeutic targets is urgently needed. Previous studies have shown that the ligand activation of the sigma-1 chaperone (Sigma1R) promotes neuroprotection. The multitarget drug afobazole (5-ethoxy-2-[2-(morpholino)-ethylthio]benzimidazole dihydrochloride) was shown to interact with Sigma1Rs and prevent decreases in striatal dopamine in the 6-hydroxydopamine (6-OHDA)-induced parkinsonism model. The aim of the present study was to elucidate the role of Sigma1Rs in afobazole pharmacological activity. Using ICR mice we found that administration of afobazole (2.5 mg/kg, i.p.) or selective agonist of Sigma1R PRE-084 (1.0 mg/kg, i.p.) over 14 days normalizes motor disfunction and prevents decreases in dopamine in the 6-OHDA-lesioned striatum. Afobazole administration also prevents the loss of TH + neurons in the substantia nigra. The preadministration of selective Sigma1R antagonist BD-1047 (3.0 mg/kg, i.p.) abolishes the activity of either afobazole or PRE-084, as determined using the rotarod test and the analysis of striatal dopamine content. The current study demonstrates the contribution of Sigma1Rs in the neuroprotective effect of afobazole in the 6-OHDA model of Parkinson's disease and defines the therapeutic perspective of Sigma1R agonists in the clinic.
\end{abstract}

Parkinson's disease is a neurodegenerative condition caused by injury in dopamine-producing regions of the brain, especially in neurons of the substantia nigra pars compacta $(\mathrm{SNc})$ and their axonal projections to the striatum. Parkinson's disease is characterized by progressive movement impairments including bradykinesia, resting tremor, rigidity and postural instability ${ }^{1}$. Epidemiological data revealed a two-fold increase in the prevalence of this disease over the last 25 years, outranked only by Alzheimer's disease among all neurodegenerative diseases ${ }^{2}$. Despite several studies suggesting the role of environmental and genetic factors, the etiology of Parkinson's disease is still poorly understood ${ }^{3}$. The main pathogenetic components of the disease are mitochondrial damage, impaired protein proteasomal degradation, misfolding, oxidative stress and neuroinflammation ${ }^{1,4-6}$. Levodopa, MAO-B and COMT inhibitors, dopamine agonists, $\beta$-blockers, and adamantane derivatives with NMDA receptor antagonism are the most commonly used treatment options ${ }^{7,8}$. The mechanism of action of these drugs involves the facilitation of dopaminergic transmission in compromised neurons or the correction of imbalance in neuromediator systems.

The Sigma-1 receptor (Sigma1R) ${ }^{9}$ is a promising target for the development of therapy for Parkinson's disease $\mathrm{e}^{10-13}$. The expression and cellular localization of Sigma1Rs in the brain have been described in previous studies $^{12,14}$. The nigrostriatal motor system has a significant level of Sigma1Rs ${ }^{15,16}$. The most important functions of Sigma1Rs include the ability for ligand activation, intracellular translocation and chaperone activity towards target proteins ${ }^{14,17,18}$. Various damaging factors lead to the accumulation of aberrant proteins, which activate the unfolded protein response (UPR) or endoplasmic-reticulum-associated protein degradation (ERAD) ${ }^{19}$. In the adaptive stage of endoplasmic reticulum (ER) stress and in response to ligand activation, Sigma1Rs dissociate from the main ER chaperone binding-immunoglobulin protein (BiP, GRP-78), which facilitates proper protein

\footnotetext{
${ }^{1}$ Federal State Budgetary Institution "Research Zakusov Institute of Pharmacology", Department of Pharmacogenetics, Baltiyskaya street 8, Moscow, 125315, Russian Federation. ${ }^{2}$ Research Center of Neurology, Laboratory of Functional Morphochemistry, Volokolamskoe Highway 80, Moscow, 125367, Russian Federation. *email: ikadnikov@gmail.com
} 
folding. Sigma1R also performs chaperone functions by stabilizing the ER stress sensor serine/threonine-protein kinase/endoribonuclease IRE1 (IRE1a) and inositol 1,4,5-trisphosphate receptor type 3 (IP3R3). These protein-protein interactions enhance the expression of ER chaperone genes, maintaining the required $\mathrm{Ca}^{2+} \mathrm{cur}^{-}$ rent in mitochondria, reducing ROS production and preventing the apoptotic transformation of neurons ${ }^{14,20-23}$. Sigma1Rs are able to bind specifically a variety of ligands ${ }^{17,24}$. In response to ligand activation, the Sigma1R enters a monomeric state and, as a part of the lipid domain, translocates to the region of nuclear and cytoplasmic membranes, where it regulates the activity of different receptors, ion channels and enzymes ${ }^{18,25}$. This activity prevents excitotoxicity and glial activation and may promote neuroprotective effects in Parkinson's disease ${ }^{26-34}$. The contribution of Sigma1Rs in the attenuation of dopamine and glutamate toxicity was previously defined using in vitro models ${ }^{22,35}$. However, studies of the effects of the Sigma1R selective agonist PRE-084 in MPTP and 6-OHDA models of Parkinson's disease produced contradictory results ${ }^{11,36}$.

The anxiolytic drug afobazole (ethoxy-2-[2-(morpholino)-ethylthio]benzimidazole dihydrochloride) was developed and pharmacologically studied at the FSBI "Research State Zakusov Institute of Pharmacology"37. The drug has affinity to Sigma1Rs $(\mathrm{Ki}=5.9 \mathrm{E}-6 \mathrm{M})$ and regulatory sites of NQO2 $(\mathrm{Ki}=9.7 \mathrm{E}-7 \mathrm{M})$ and MAO A $(\mathrm{Ki}=3.6 \mathrm{E}-06 \mathrm{M})^{38}$. In vitro and in vivo experiments with afobazole revealed cytoprotective and neuroprotective properties of the drug ${ }^{39-42}$. Our recent results showed the ability of afobazole to prevent decreases in striatal dopamine in the model of 6-OHDA-induced parkinsonism ${ }^{43}$; however, the role of the above mentioned molecular targets of afobazole has not been defined. The aim of the present study was to determine the role of SigmalRs in the afobazole-mediated normalizing effect on dopamine content in the striatum in an in vivo mouse model of Parkinson's disease induced by 6-OHDA lesions.

\section{Results}

We found that the DA content in the 6-OHDA lesioned striatum of vehicle-treated mice decreased two-fold compared to that in the contralateral striatum and in the damaged striatum of sham-operated mice (Fig. 1). Treatment with afobazole at $2.5 \mathrm{mg} / \mathrm{kg}$ for 14 days starting 30 minutes after the surgery markedly mitigated neurotoxic action, bringing DA content to the level observed in the damaged striatum of sham-operated mice (Fig. 1). The Sigma1R agonist PRE-084 administered at $1.0 \mathrm{mg} / \mathrm{kg}$ had a similar effect to that of afobazole (Fig. 1). The pre-administration of the selective Sigma1R antagonist BD-1047 at a dose of $3.0 \mathrm{mg} / \mathrm{kg}$ abolished the action of afobazole and PRE-084. The vulnerability of the PRE-084 effect was of higher significance (Fig. 1). The DOPAC level was decreased in the 6-OHDA lesioned striatum in vehicle-treated mice compared to that in the contralateral striatum and in the damaged striatum of sham-operated mice and was correlated with decreased DA content (Fig. 2). Although DA concentration increased in response to afobazole treatment, DOPAC content was in an intermediate range between concentrations observed in sham-operated and 6-OHDA-lesioned mice (Fig. 2). The administration of the Sigma1R agonist PRE-084 markedly increased DOPAC content compared to that in the 6-OHDA lesioned mice and restored DA content to the value observed in the control group (Fig. 2). In contrast, the Sigma1R antagonist BD-1047 administered daily 30 minutes prior to afobazole or PRE-084 diminished DOPAC content to the level of that in 6-OHDA lesioned vehicle-treated mice. BD-1047 markedly counteracted the action of PRE-084 (Fig. 2).

Similar to the DOPAC content, the content of HVA was also reduced in the lesioned striatum of vehicle-treated mice, and afobazole had no significant effect on this value (Fig. 3). The HVA content in the 6-OHDA-lesioned striatum of PRE-084-treated mice was lower than that in the intact striatum but was markedly higher than that in the lesioned striatum of vehicle-treated mice. The pre-administration of the Sigma1R antagonist BD-1047 affects afobazole- and PRE-084-treated mice, preventing an increase in HVA (Fig. 3). No significant differences in DA, DOPAC and HVA contents were detected in intact striatum between experimental groups (Figs 1-3). The metabolic ratios DOPAC/DA, HVA/DA and (DOPAC + HVA)/DA were significantly elevated in the 6-OHDA lesioned striatum of vehicle-treated mice. Afobazole treatment lowered the HVA/DA and (DOPAC $+\mathrm{HVA}) / \mathrm{DA}$ ratios, whereas PRE-084 had no detectable effect (Table 1).

Prolonged treatment with afobazole at a dose of $2.5 \mathrm{mg} / \mathrm{kg}$ preserved DA content in the 6-OHDA lesioned striatum, was accompanied by a marked increase in the relative number of TH+ neurons in the SNc (Fig. 4) and latency to fall in rotarod test (S. Fig. 1). A strong positive correlation was revealed between the DA level and the number of SNc TH+ neurons $(\mathrm{R}=0.85, \mathrm{p}<0.00001)$ (Fig. 5).

In the rotarod test, the median latency to fall of vehicle-treated mice with 6-OHDA lesions decreased five-fold compared to that of sham-operated animals (Fig. 6). Afobazole and PRE-084 significantly increased the latency to fall in hemiparkinsonic animals. The pre-administration of BD-1047 antagonized afobazole action. Similarly, pretreatment with BD-1047 decreased the latency to fall of PRE-084-treated mice compared to that of sham-operated mice or mice treated with PRE-084 (Fig. 6). No significant difference in the latency to fall in the rotarod test was observed in naive intact and vehicle-treated animals versus sham-operated mice (S. Fig. 2). The ligands of the Sigma1R and its combinations did not affect the performance of naive mice in the rotarod test (S. Fig. 2). Our data show a strong positive correlation between DA content in the striatum and latency to fall $(\mathrm{R}=0.77, \mathrm{p}<0.00001)$ (Fig. 7).

K-means data clustering demonstrated the partitioning of experimental mice into two major groups. The first cluster was represented by sham-operated and afobazole- or PRE-084-treated mice (except case \#28), while the second cluster consisted of vehicle-treated or BD-1047-pretreated mice (except cases \#12, \#42, \#48, \#55, and \#56). Animals whose experimental characteristics stood out from those of the group and turned out to be in the opposite cluster were at the maximum distance from the center of their cluster (Fig. 7). 


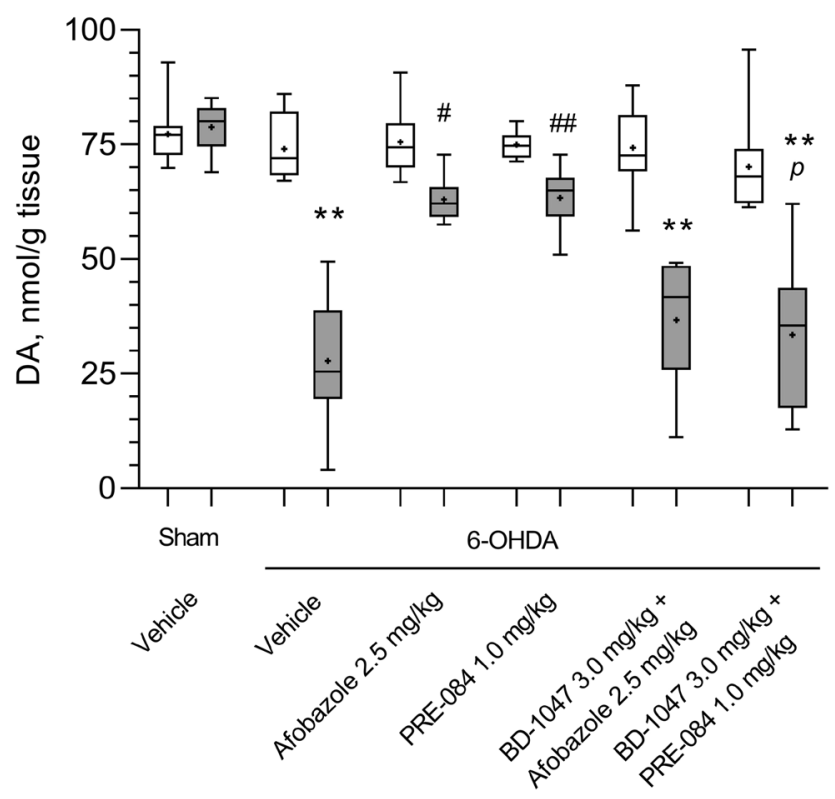

Figure 1. The influence of Sigma1R ligand administration over 14 days on dopamine content in the intact and 6-OHDA lesioned striatum of ICR mice. Data are presented as the Mdn (min-max). "+" - the mean. Sham - shamoperated mice. 6-OHDA - 6-OHDA-lesioned mice. Experimental groups consisted of 10 mice except for afobazoletreated only, which was 9 . A significant difference between the contra- and ipsilateral striata was observed in all experimental groups with 6-OHDA lesions ( $\mathrm{p}<0.01$, Wilcoxon test). $\square$-contralateral striatum, $\square$ - ipsilateral striatum. $* * \mathrm{p}<0.01$ - statistical significance versus lesioned striatum of sham-operated mice (Kruskal-Wallis test, Dunn's post hoc test). ${ }^{\#} \mathrm{p}<0.05,{ }^{\#} \mathrm{p}<0.01$ - statistical significance versus 6-OHDA lesioned striatum of vehicletreated mice (Kruskal-Wallis test, Dunn's post hoc test). ${ }^{p} \mathrm{p}<0.05$ - statistical significance versus 6-OHDA lesioned striatum of PRE-084-treated mice (Kruskal-Wallis test, Dunn's post hoc test).

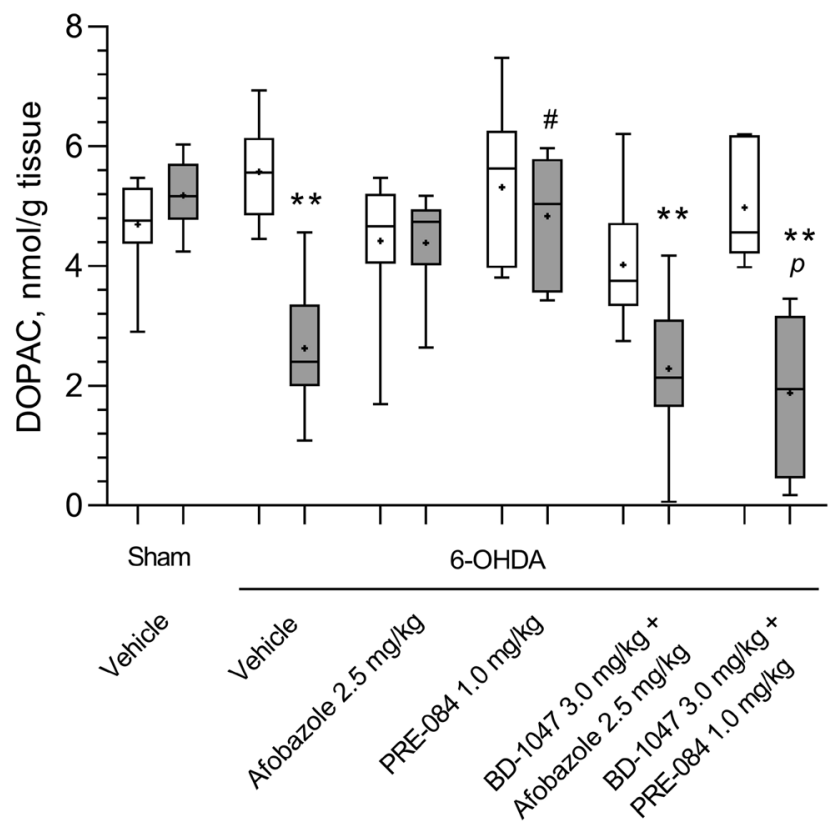

Figure 2. The influence of Sigma1R ligand administration over 14 days on dihydroxyphenylacetic acid content in the intact and 6-OHDA-lesioned striatum of ICR mice. Data are presented as the Mdn (min-max). "+" - the mean. Sham - sham-operated mice. 6-OHDA - 6-OHDA-lesioned mice. Experimental groups consisted of 10 mice except for afobazole-treated only, which was 9. A significant difference between the contra- and ipsilateral striata was observed in animals with 6-OHDA lesions that received vehicle or a combination of BD-1047 with afobazole or PRE-084 ( $<<0.01$, Wilcoxon test). $\square$ - contralateral striatum, $\square$ - ipsilateral striatum. $* * \mathrm{p}<0.01$ - statistical significance versus lesioned striatum of sham-operated mice (Kruskal-Wallis test, Dunn's post hoc test). ${ }^{*} \mathrm{p}<0.05$ - statistical significance versus 6-OHDA lesioned striatum of vehicle treated mice (Kruskal-Wallis test, Dunn's post hoc test). ${ }^{p} \mathrm{p}<0.05$ - statistical significance versus 6-OHDA lesioned striatum of PRE-084-treated mice (Kruskal-Wallis test, Dunn's post hoc test). 


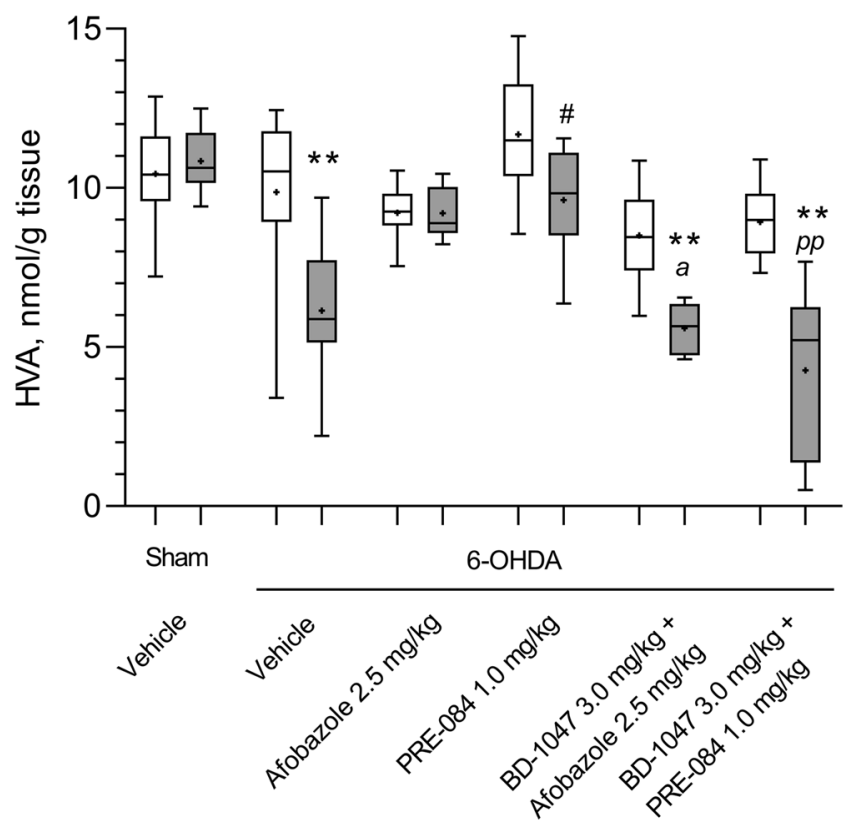

Figure 3. The influence of Sigma1R ligand administration over 14 days on homovanillic acid content in the intact and 6-OHDA-lesioned striatum of ICR mice. Data are presented as the Mdn (min-max). "+" - the mean. Sham - sham-operated mice. 6-OHDA - 6-OHDA-lesioned mice. Experimental groups consisted of 10 mice except for afobazole-treated only, which was 9. A significant difference between the contra- and ipsilateral striata was observed in animals with 6-OHDA lesions that received vehicle and PRE-084 ( $<<0.05$, Wilcoxon test), a combination of BD-1047 with afobazole or PRE-084 ( $<<0.01$, Wilcoxon test). $\square$-contralateral striatum, $\square$ - ipsilateral striatum. ${ }^{* *} \mathrm{p}<0.01$ - statistical significance versus lesioned striatum of shamoperated mice (Kruskal-Wallis test, Dunn's post hoc test). \#p $<0.05$ - statistical significance versus 6-OHDA lesioned striatum of vehicle-treated mice (Kruskal-Wallis test, Dunn's post hoc test). ${ }^{a} \mathrm{p}<0.05$ - statistical significance versus 6-OHDA lesioned striatum of afobazole-treated mice (Kruskal-Wallis test, Dunn's post hoc test). ${ }^{p p} \mathrm{p}<0.01$ - statistical significance versus 6-OHDA lesioned striatum of PRE-084-treated mice (KruskalWallis test, Dunn's post hoc test).

\section{Discussion}

The current study, for the first time, characterizes the contribution of Sigma1Rs in the neuroprotective effects of afobazole in an in vivo 6-OHDA model of Parkinson's disease. The unilateral intrastriatal injection of 6-OHDA leads to a decrease in the DA content in the striatum, which is cross-correlated with the death of TH+ neurons in the SNc and low latency to fall in the rotarod test. These phenotypic characteristics represent pathogenetic mechanisms of Parkinson's disease and are consistent with previously reported results in this model ${ }^{44,45}$. Afobazole administered at a dose of $2.5 \mathrm{mg} / \mathrm{kg}$ prevents the development of disorders caused by neurotoxicity, therefore demonstrating its neuroprotective activity proven by the high cross-correlation between DA content in the striatum and latency to fall in the rotarod test or TH+ count. Neuroprotection in the 6-OHDA model of Parkinson's disease is characterized by the prevention of $\mathrm{TH}+$ neuron death and the normalization of DA content in the striatum and movement activity ${ }^{13,46,47}$. A significant decrease in DA metabolic ratios caused by afobazole is also in line with experimental data that characterize neuroprotection in models of Parkinson's disease $\mathrm{e}^{11,48}$.

The effects of afobazole and the Sigma1R agonist PRE-084 administered at $1.0 \mathrm{mg} / \mathrm{kg}$ show many similarities, as confirmed by cluster analysis. One of the two clusters of experimental animals was represented by sham-operated mice and mice that received afobazole or PRE-084 only. The observed effect of afobazole is consistent with the previously described neuroprotective effect of PRE-084 in C57BL/6 mice in the 6-OHDA model of Parkinson's disease ${ }^{11}$.

Pre-treatment with the selective Sigma1R antagonist BD-1047 abolished the restorative effect of afobazole on DA content, as well as the latency to fall in the rotarod test. These results suggest that Sigma1Rs are implicated in afobazole pharmacological activity. The clustering of vehicle-treated animals with animals that received BD-1047 pretreatment prior to afobazole and PRE-084 administration implies that BD-1047 interferes with afobazole and PRE-084 activity in a similar manner. The effects of afobazole on DA and DOPAC content and latency to fall in the rotarod test were less affected by BD-1047 pre-administration than PRE-084. These observations may argue for the existence of additional molecular mechanisms, in addition to Sigma1Rs, that mediate the neuroprotective effect of afobazole ${ }^{38,49,50}$. Thus, the lack of significant elevation in DOPAC content, along with the normalization of DA levels after afobazole treatment, suggests the inhibition of MAO-A by the drug ${ }^{49}$, which may facilitate the neuroprotective action of afobazole on neurons of the nigrostriatal pathway ${ }^{51}$. The results obtained in our study are consistent with previously published data on the cytoprotective and neuroprotective effects of afobazole, demonstrating the role of Sigma1Rs in the activation of antiparkinsonian mechanisms. 6-OHDA was shown to cause abundant $\mathrm{Ca}^{2+}$ uptake in neurons ${ }^{52}$. In models of acidosis and cortical neuron ischemia, the administration 


\begin{tabular}{|c|c|c|c|c|c|}
\hline \multicolumn{2}{|c|}{ Experimental groups } & \multirow{2}{*}{$\begin{array}{l}\text { DOPAC/DA } \\
\mathrm{C} \\
\mathrm{n}=10\end{array}$} & \multirow{2}{*}{$\begin{array}{l}\text { HVA/DA } \\
0.06 \\
(0.06-0.07) \\
\end{array}$} & \multicolumn{2}{|c|}{$(\mathrm{DOPAC}+\mathrm{HVA}) / \mathrm{DA}$} \\
\hline \multirow{2}{*}{ Sham } & \multirow{2}{*}{ Vehicle } & & & $\begin{array}{l}0.14 \\
(0.13-0.15)\end{array}$ & \begin{tabular}{|l|}
0.2 \\
$(0.19-0.21)$
\end{tabular} \\
\hline & & $\begin{array}{l}\mathrm{I} \\
\mathrm{n}=10\end{array}$ & $\begin{array}{l}0.07 \\
(0.06-0.07)\end{array}$ & $\begin{array}{l}0.14 \\
(0.13-0.15)\end{array}$ & $\begin{array}{l}0.2 \\
(0.19-0.22) \\
\end{array}$ \\
\hline \multirow{10}{*}{ 6-OHDA } & \multirow[b]{2}{*}{ Vehicle } & $\begin{array}{l}\mathrm{C} \\
\mathrm{n}=10\end{array}$ & $\begin{array}{l}0.08 \\
(0.07-0.09)\end{array}$ & $\begin{array}{l}0.14 \\
(0.11-0.16)\end{array}$ & $\begin{array}{ll}0.21 \\
(0.19-0.24) \\
\end{array}$ \\
\hline & & $\begin{array}{l}\mathrm{I} \\
\mathrm{n}=10\end{array}$ & $\begin{array}{l}0.1 \\
(0.08-0.12) \\
* * \mathrm{p}=0.007 \\
\wedge \mathrm{p}=0.0195\end{array}$ & $\begin{array}{l}0.23 \\
(0.19-0.3) \\
* * p=0.0006 \\
\wedge \wedge p=0.002\end{array}$ & $\begin{array}{l}0.32 \\
(0.27-0.42) \\
* * \mathrm{p}=0.0005 \\
\wedge \wedge \mathrm{p}=0.002\end{array}$ \\
\hline & \multirow[b]{2}{*}{ afobazole (2,5 mg/kg) } & $\begin{array}{l}\mathrm{C} \\
\mathrm{n}=9\end{array}$ & $\begin{array}{l}0.06 \\
(0.05-0.07)\end{array}$ & $\begin{array}{l}0.13 \\
(0.11-0.14)\end{array}$ & $\begin{array}{l}0.19 \\
(0.16-0.2)\end{array}$ \\
\hline & & $\begin{array}{l}\mathrm{I} \\
\mathrm{n}=9\end{array}$ & $\begin{array}{l}0.07 \\
(0.06-0.08)\end{array}$ & $\begin{array}{l}0.14 \\
(0.13-0.16) \\
{ }^{p} \mathrm{p}=0.014 \\
\wedge \wedge \mathrm{p}=0.0039\end{array}$ & $\begin{array}{l}0.22 \\
(0.2-0.23) \\
{ }^{\#} \mathrm{p}=0.016 \\
\wedge \mathrm{p}=0.027\end{array}$ \\
\hline & \multirow{2}{*}{$\begin{array}{l}\text { PRE-084 } \\
(1 \mathrm{mg} / \mathrm{kg})\end{array}$} & $\begin{array}{l}\mathrm{C} \\
\mathrm{n}=10\end{array}$ & $\begin{array}{l}0.08 \\
(0.06-0.08)\end{array}$ & $\begin{array}{l}0.15 \\
(0.14-0.17)\end{array}$ & $\begin{array}{l}0.24 \\
(0.2-0.25)\end{array}$ \\
\hline & & $\begin{array}{l}\mathrm{I} \\
\mathrm{n}=10\end{array}$ & $\begin{array}{l}0.08 \\
(0.07-0.09)\end{array}$ & $\begin{array}{l}0.16 \\
(0.14-0.17) \\
\end{array}$ & \begin{tabular}{|l|}
0.24 \\
$(0.21-0.26)$ \\
\end{tabular} \\
\hline & \multirow{2}{*}{$\begin{array}{l}\text { BD-1047 } \\
(3 \mathrm{mg} / \mathrm{kg})+\text { afobazole }(2,5 \mathrm{mg} / \mathrm{kg})\end{array}$} & $\begin{array}{l}\mathrm{C} \\
\mathrm{n}=10\end{array}$ & $\begin{array}{l}0.05 \\
(0.05-0.06)\end{array}$ & $\begin{array}{l}0.11 \\
(0.11-0.13) \\
\mathrm{p}=0.044 \\
\wedge \wedge \mathrm{p}=0.0059\end{array}$ & $\begin{array}{l}0.16 \\
(0.16-0.18) \\
\wedge p=0.037\end{array}$ \\
\hline & & $\mathrm{I}$ & $\begin{array}{l}0.06 \\
(0.04-0.09) \\
{ }^{*} \mathrm{p}=0.019\end{array}$ & $\begin{array}{l}0.14 \\
(0.13-0.24)\end{array}$ & $\begin{array}{l}0.22 \\
(0.18-0.33) \\
{ }^{\#} \mathrm{p}=0.028 \\
\end{array}$ \\
\hline & \multirow{2}{*}{$\begin{array}{l}\text { BD- } 1047 \\
(3 \mathrm{mg} / \mathrm{kg})+\text { PRE- } 084 \\
(1 \mathrm{mg} / \mathrm{kg})\end{array}$} & $\begin{array}{l}\mathrm{C} \\
\mathrm{n}=10\end{array}$ & $\begin{array}{l}0.07 \\
(0.07-0.08)\end{array}$ & $\begin{array}{l}0.13 \\
(0.12-0.14)\end{array}$ & $\begin{array}{ll}0.2 \\
(0.19-0.21) \\
\end{array}$ \\
\hline & & $\mathrm{I}=10$ & $\begin{array}{l}0.06 \\
(0.02-0.09) \\
\# \mathrm{p}=0.046\end{array}$ & $\begin{array}{l}0.15 \\
(0.04-0.22) \\
{ }^{\#} \mathrm{p}=0.033\end{array}$ & $\begin{array}{l}0.22 \\
(0.06-0.32) \\
\# \mathrm{p}=0.026\end{array}$ \\
\hline
\end{tabular}

Table 1. The influence of Sigma1R ligand administration over 14 days on dopamine turnover in intact and 6-OHDA- lesioned striatum of ICR mice. Data are presented as the Mdn (q25-75). Sham - sham-operated mice. 6-OHDA - 6-OHDA-lesioned mice. C- contralateral (intact) striatum, I - ipsilateral (lesioned) striatum Kruskal-Wallis test, Dunn's post hoc test: $* * \mathrm{p}<0.01$ - statistical significance versus lesioned striatum of shamoperated mice. ${ }^{\#} \mathrm{p}<0,05$ - statistical significance versus 6-OHDA lesioned striatum of vehicle treated mice. Wilcoxon test: $\wedge p<0.05, \wedge \wedge p<0.01$ - statistical significance versus contralateral striatum.

of afobazole substantially decreased $\mathrm{Ca}^{2+}$ uptake; however, the use of the selective Sigma1R antagonists BD-1047 and $\mathrm{BD}-1063$ weakened this effect ${ }^{53}$. The activation of microglia is an important component of Parkinson's disease pathogenesis; in fact, microglia activation was observed after 6-OHDA injection, suggesting the relevance of this animal model ${ }^{54,55}$. Injured neurons release ATP and UTP, which serve as signaling molecules mediating microglial activation. Afobazole blocked the migration of microglia into the region with increased concentrations of ATP and UTP in vitro, while selective Sigma1R antagonists prevented this effect ${ }^{56}$. Moreover, the Sigma1R antagonist BD-1047 also decreased the suppressive effect of afobazole on microglial activation by $\mathrm{A} \beta_{25-35}{ }^{57}$. In our previous studies, the effects of afobazole were ablated by a sigma- 2 receptor antagonist ${ }^{56,57}$. Afobazole does not interact with the sigma-2 receptor, as demonstrated by a binding assay ${ }^{38}$. Sigma1Rs and sigma- 2 receptors are different proteins encoded by diverse genes ${ }^{9,58,59}$. The interconnection of these two proteins in physiological processes is poorly understood ${ }^{60-62}$. However, the sigma-2 receptor may be a part of the protective pathway that is triggered by the interaction of the Sigma1R chaperone with afobazole. The development of Parkinson's disease and other neurodegenerative conditions is accompanied by impaired protein folding and the presence of protein aggregates followed by neuronal dystrophy. The main ER chaperone BiP is found in complex with Sigma1R. Activation induced by Sigma1R agonists causes the dissociation of that complex and the activation of $\mathrm{BiP}^{14,63,64}$. There is evidence that Sigma1R contributes to the regulation of the proteasomal degradation of aberrant proteins, amyloid in particular ${ }^{65,66}$. It is known that amyloid proteins can accumulate within cells, causing neurotoxicity ${ }^{67,68}$. Afobazole increases the survival of cortical neurons incubated with amyloid $A \beta_{25-35}$ by inhibiting excessive $\mathrm{Ca}^{2+}$ uptake and NO production. The selective Sigma1R antagonist BD-1047 also prevented this action of afobazole ${ }^{57}$. The development of Parkinson's disease is accompanied by the increased production of quinone compounds, such as dopamine quinone $e^{69,70}$, as well as by oxidative stress ${ }^{71,72}$. The contribution of Sigma1Rs to the protective effect of afobazole in the model of menadione cytotoxicity was also previously reported by our group ${ }^{39}$.

Taken together, the current study demonstrates the important role of Sigma1Rs in the neuroprotective effect of afobazole in the 6-OHDA model of Parkinson's disease and suggests that the use of Sigma1R agonists could be beneficial as a Parkinson's disease treatment. 

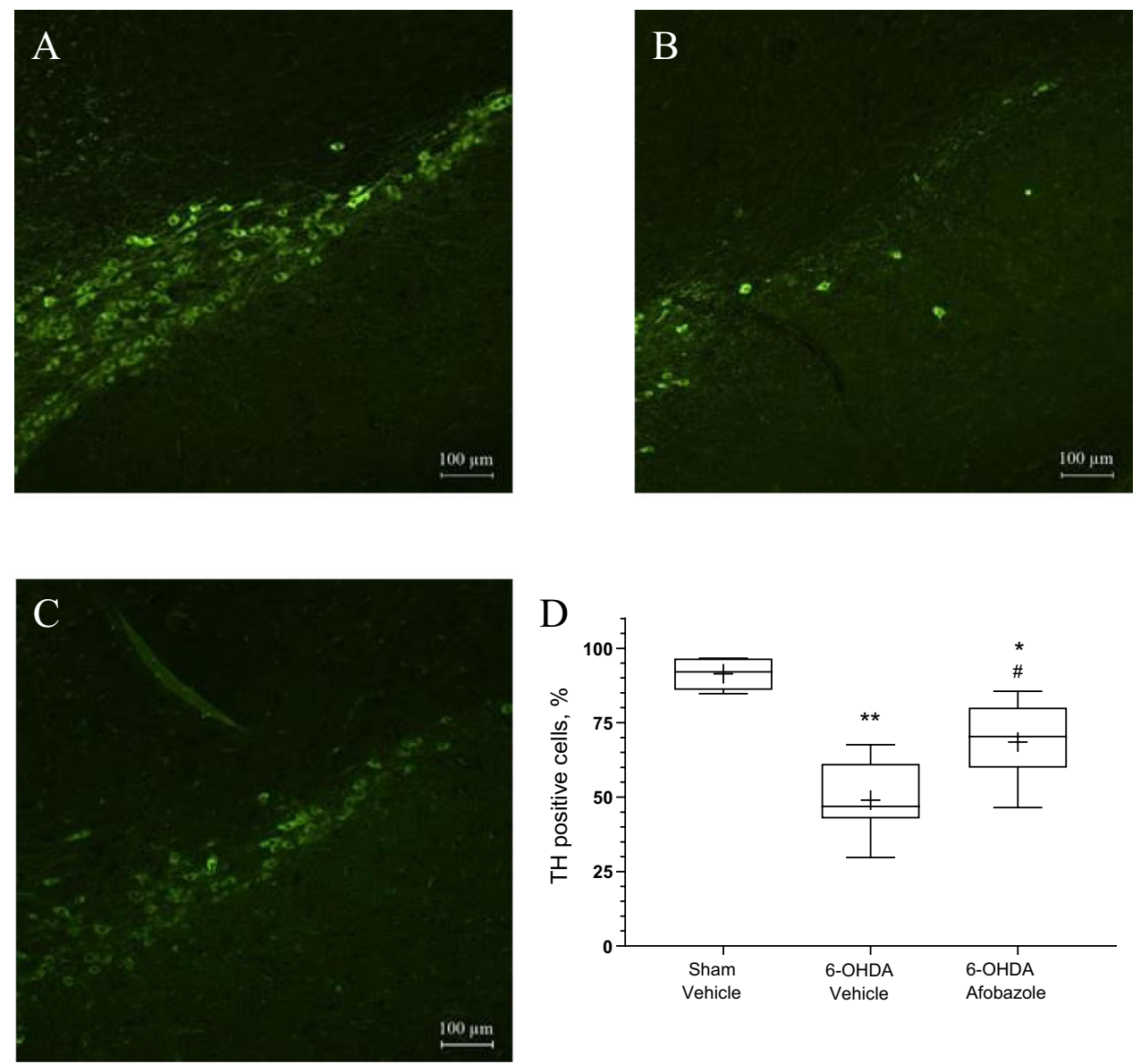

Figure 4. The influence of afobazole on the count of $\mathrm{TH}+$ neurons in the ipsilateral SNc in the model of Parkinson's disease induced by a single injection of 6-OHDA. (A) Sham-operated mice $(n=6)$. (B) Mice with 6-OHDA lesions $(n=7)$. (C) Afobazole-treated mice with 6-OHDA lesions $(n=9)$. Imaging was carried out at 10x magnification. (D) TH-positive cell count. The count was performed in 3-6 slices of the SNc (rostral, medial and caudal regions) from each animal obtained under the same microscopy conditions: 40x magnification, exposition time $800 \mathrm{~ms}$, and 1.1 gain. The density of SNc neurons on the ipsilateral side is expressed as a percentage of that on the contralateral side. Data are presented as the Mdn (min-max). " + " - the mean. Sham sham-operated mice. 6-OHDA - 6-OHDA-lesioned mice. ${ }^{*} \mathrm{p}<0.05, * * \mathrm{p}<0.01$ - statistical significance versus sham-operated mice (ANOVA, Holm-Sidak post hoc test). ${ }^{*} \mathrm{p}<0.05$ - statistical significance versus 6-OHDA lesioned mice treated with vehicle (ANOVA, Holm-Sidak post hoc test).

\section{Methods}

Chemicals. The following chemicals were used: afobazole (5-ethoxy-2-[2-(morpholino)-ethylthio]benzimidazole dihydrochloride) (FSBI "Research State Zakusov Institute of Pharmacology"), PRE-084 (Tocris), BD-1047 (Tocris), 6-hydroxydopamine hydrochloride (6-OHDA), ascorbic acid, $\mathrm{NaCl}$, sucrose, paraformaldehyde (PFA), polyclonal antibodies against tyrosine hydroxylase T8700 (Sigma-Aldrich), secondary antibodies conjugated with CF488 fluorochrome SAB4600045 (Sigma-Aldrich), FluoroShield, 4',6-diamidino-2-phenylindole, Triton X-100, chloral hydrate, 3,4-dihydroxybenzylamine hydrobromide (DHBA), dopamine (DA), 3,4-dihydroxyphenylacetic acid (DOPAC), homovanillic acid (HVA), $\mathrm{KH}_{2} \mathrm{PO}_{4}, \mathrm{H}_{3} \mathrm{PO}_{4}, \mathrm{HClO}_{4}$, citric acid, EDTA-Na , octanesulfonic acid, acetonitrile, and Tissue Tek O.C.T. medium.

Experimental animals. The study was performed in male ICR (CD-1) mice (25-30 g, $\mathrm{n}=152)$ obtained from Pushchino Breeding Center (Branch of the Institute of Bioorganic Chemistry, Russian Academy of Sciences). Animals were housed under standard vivarium conditions $\left(20-22^{\circ} \mathrm{C}, 30-70 \%\right.$ humidity, 12 -hour light/ dark cycle) in plastic cages with sawdust bedding and 10 animals per cage.

Ethical approval. All experimental procedures were approved by the bioethics committee of the FSBI "Research Zakusov Institute of Pharmacology". All applicable national ${ }^{73}$ and international ${ }^{74}$ guidelines for the care and use of experimental animals were followed.

6-OHDA lesion. Thirty minutes prior to surgery, the animals were anesthetized with chloral hydrate $(400 \mathrm{mg} /$ $\mathrm{kg}$ intraperitoneally) ${ }^{45,75}$. Anesthetized animals were placed into the stereotaxic frame (Stoelting Co., United 


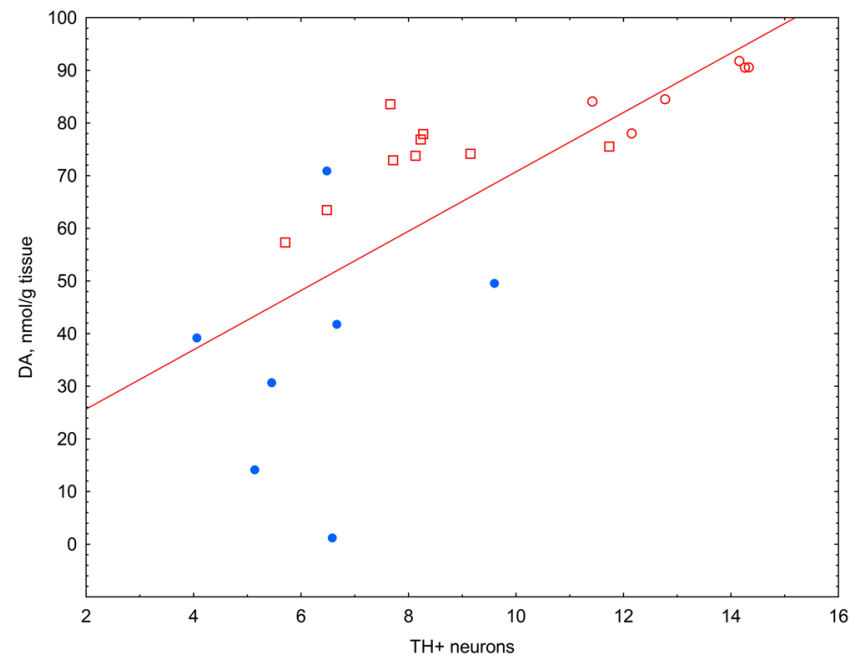

Figure 5. Correlation analysis of the $\mathrm{TH}+$ neuron count in the ipsilateral SNc and DA content in the striatum. Light circle - sham-operated vehicle-treated animals $(n=6)$; dark circle - 6-OHDA-lesioned vehicle-treated animals $(\mathrm{n}=7)$; light square - 6-OHDA-lesioned afobazole-treated animals at a dose of $2.5 \mathrm{mg} / \mathrm{kg}(\mathrm{n}=9)$; blue color - cluster 2 , red color - cluster $1 ; \mathrm{R}=0.85 \mathrm{p}=0.000001$; line of best fit equation $\mathrm{DA}=14.395+5.6337 * \mathrm{x}$.

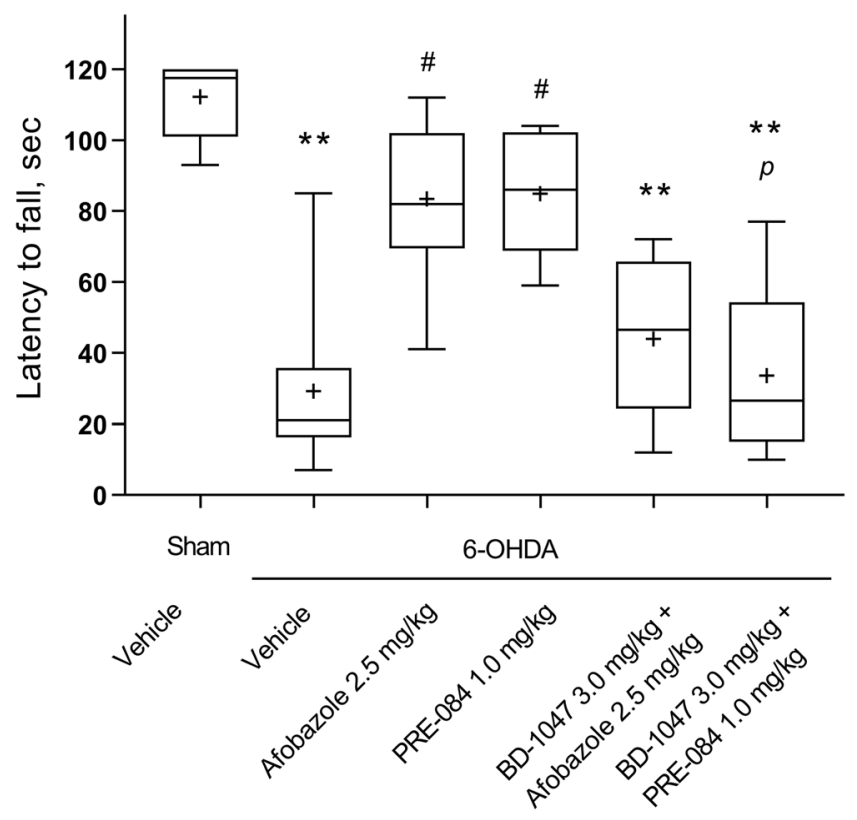

Figure 6. The influence of Sigma1R ligand administration over 14 days on latency to fall during a fixed-speed rotarod test in 6-OHDA-lesioned ICR mice. Data are presented as the Mdn (min-max). "+" - the mean. Sham sham-operated mice. 6-OHDA - 6-OHDA-lesioned mice. Experimental groups consisted of 10 mice except for afobazole-treated only, which was 9 . **p $<0.01$ - statistical significance versus sham-operated mice (KruskalWallis test, Dunn's post hoc test). \#p $<0.05$ - statistical significance versus 6-OHDA-lesioned mice treated with vehicle (Kruskal-Wallis test, Dunn's post hoc test). ${ }^{p} \mathrm{p}<0.05$ - statistical significance versus 6-OHDA-lesioned mice treated with PRE-084 (Kruskal-Wallis test, Dunn's post hoc test).

Kingdom), and 6-OHDA was injected into the right striatum according to the coordinates $\mathrm{A}=0.4, \mathrm{~L}=1.8$, and $\mathrm{V}=-3.5$ relative to bregma ${ }^{45}$. 6-OHDA was dissolved at $5 \mu \mathrm{g}$ per $1 \mu \mathrm{L}$ of a solution containing $0.9 \% \mathrm{NaCl}$ and $0.02 \%$ ascorbic acid. The experimental animals were injected with $1 \mu \mathrm{L}$ of the 6-OHDA solution at a rate of $0.5 \mu \mathrm{L} /$ min using a Hamilton syringe equipped with a 30-gauge stainless steel needle. The needle was withdrawn 2 min after the injection. Sham-operated animals were injected with $1 \mu \mathrm{L}$ of saline with $0.02 \%$ ascorbic acid at the same coordinates.

Treatment with drugs. All drug substances were dissolved in water for injections immediately before administration and were intraperitoneally injected at a volume of $0.1 \mathrm{ml} / 10 \mathrm{~g}$ body weight. Afobazole at a dose 


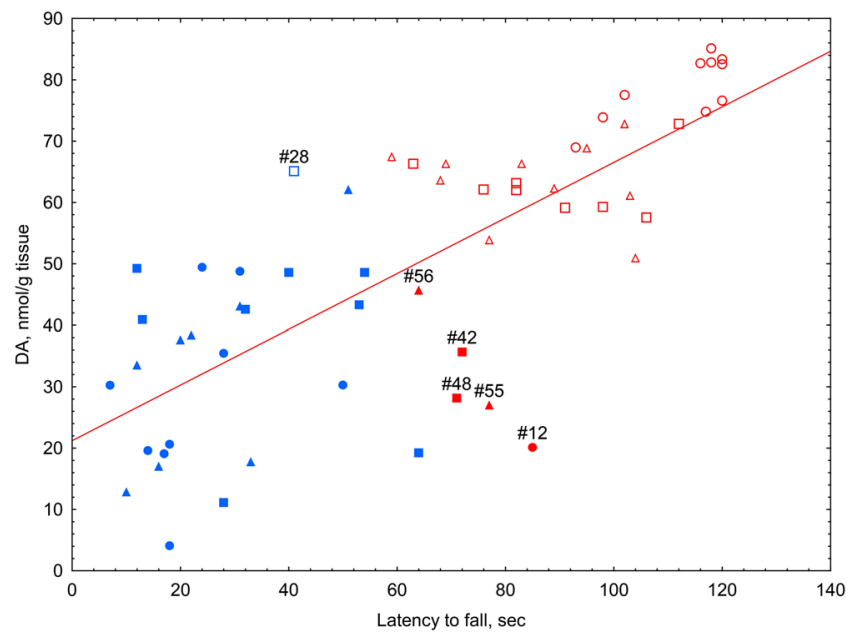

Figure 7. Correlation and cluster analysis of the association between striatal DA content and the latency to fall in the rotarod test. Light circle - sham-operated vehicle-treated animals; dark circle - 6-OHDA-lesioned vehicle-treated animals; light square - 6-OHDA-lesioned afobazole-treated animals at a dose of $2.5 \mathrm{mg} / \mathrm{kg}$; dark square - 6-OHDA-lesioned afobazole-treated animals at a dose of $2.5 \mathrm{mg} / \mathrm{kg}$ with BD-1047 pretreatment at a dose of $3.0 \mathrm{mg} / \mathrm{kg}$; light triangle - 6-OHDA-lesioned PRE-084-treated animals at a dose of $1 \mathrm{mg} / \mathrm{kg}$; dark triangle - 6-OHDA-lesioned PRE-084- treated animals at a dose of $1.0 \mathrm{mg} / \mathrm{kg}$ with BD-1047 pretreatment at a dose of $3.0 \mathrm{mg} / \mathrm{kg}$; blue color - cluster 2, red color - cluster 1 . K-means data clustering demonstrated that the first cluster consisted of sham-operated and afobazole- or PRE-084-treated mice (except case \#28). The second cluster consisted of vehicle-treated or BD-1047 pretreated mice (except cases \#12, \#42, \#48, \#55, and \#56). $\mathrm{R}=0,77 \mathrm{p}=0,000000$; line of best fit equation $\mathrm{DA}=21,2193+0,4532 * \mathrm{x}$. Experimental groups consisted of 10 mice except for afobazole-treated only, which was 9.

of $2.5 \mathrm{mg} / \mathrm{kg}$, PRE-084 at a dose of $1.0 \mathrm{mg} / \mathrm{kg}$ or vehicle were injected daily for 14 days, with course starting 30 minutes after surgery. The selective Sigma1R antagonist BD-1047, at a dose of $3.0 \mathrm{mg} / \mathrm{kg}$, was injected $30 \mathrm{~min}-$ utes prior to afobazole or PRE-084. The animals were divided as follows. Sham-operated vehicle-treated mice $(\mathrm{n}=10)$ and five groups with 6-OHDA lesions: mice treated with afobazole $(\mathrm{n}=9)$, PRE-084 $(\mathrm{n}=10), \mathrm{BD}-1047$ following the administration of afobazole $(n=10)$ or PRE-084 $(n=10)$, and vehicle-treated $(n=10)$. One animal with a 6-OHDA lesion that received afobazole was excluded because of death during surgery. To verify whether compounds used in the study affect motor behavior in rotarod test, 70 naive mice were divided into the following groups: intact mice $(\mathrm{n}=10)$, animals that received vehicle $(\mathrm{n}=10)$, afobazole $(\mathrm{n}=10)$, PRE-084 $(\mathrm{n}=10)$, BD-1047 $(n=10)$ and a combination of BD-1047 and afobazole $(n=10)$ or PRE-084 $(n=10)$. Additional 22 animals used for immunohistochemical assay were divided as follows: sham-operated vehicle-treated mice $(n=6)$ and two groups of mice with 6-OHDA lesions vehicle- $(n=7)$ and afobazole-treated $(n=9)$.

All animals were treated with the same doses of studied compounds for 14 days, except for naive intact animals.

Rotarod test. Motor behavior was studied in male ICR mice utilizing a Rota-rod/RS LE 8500 apparatus (Panlab/Harvard apparatus). Two training sessions spaced 24 hours apart were performed to acclimate the experimental animals to the apparatus and to exclude hypodynamic animals from the study. The first training session was performed on the twelfth day after surgery. Each animal was placed on the rod twice as it rotated at a rate of $4 \mathrm{rpm}$, with a 1-hour interval between sessions. During the second session, the rotation speed was increased to $10 \mathrm{rpm}$. Animals unable to hold on to the rod for more than 1 minute were excluded from the study ${ }^{44}$. In the present study, all animals were able to hold on to the rod for more than one minute, so none of them were excluded from the experiment.

On the 14th day after surgery, mice were placed onto a rod rotating at $20 \mathrm{rpm}$, and latency to fall was measured. Each animal was tested three times, with 30-minute intervals between attempts. If the experimental animal was able to hold on to the rod for $120 \mathrm{~s}$, the measurement of time was stopped. The maximum time of the three attempts was used for statistical analysis. On days with training sessions and the rotarod test, drugs were administered after pretraining or testing.

HPLC-ED technique. Dopamine and its metabolites were measured in the damaged and intact striata of the mouse brain using the high-performance liquid chromatography technique with electrochemical detection (HPLC-ED). Fourteen days after the 6-OHDA administration, the mice were decapitated, and the brains were removed. The left and right striata were dissected on wet ice covered with filter paper dampened in $0.32 \mathrm{M}$ sucrose solution at a temperature of $0-4^{\circ} \mathrm{C}$. Each striatum was frozen in liquid nitrogen $\left(-196^{\circ} \mathrm{C}\right)$, weighed, and stored at $-80^{\circ} \mathrm{C}$. To measure the contents of dopamine and its metabolites, the striatum was homogenized in $0.1 \mathrm{M} \mathrm{HClO}_{4}$ in a TissueLyserLT bead homogenizer (Qiagen, Germany) at a frequency of $45 \mathrm{bit} / \mathrm{min}$ for 5 minutes. DHBA was added as an internal standard at a concentration of $0.25 \mathrm{nmol} / \mathrm{mL}$. The samples were centrifuged at $10000 \mathrm{~g}$ and 
$4^{\circ} \mathrm{C}$ for $10 \mathrm{~min}$. Twenty $\mu \mathrm{L}$ of the supernatant was applied onto a Kromasil C-18 $4.6 \times 150$ analytical column (Dr. Maisch, Germany) using an SIL-20 ACHT autosampler (Shimadzu, Japan). Monoamines and their metabolites were separated in the column using $0.1 \mathrm{M}$ citrate-phosphate buffer containing $0.3 \mathrm{~mm}$ sodium octanesulfonate, $0.1 \mathrm{~mm}$ EDTA, and $8 \%$ acetonitrile ( $\mathrm{pH} 3.0)$ as the mobile phase. Determination of dopamine and its metabolites was performed using a Shimadzu LC-20 Prominence chromatographic station (Shimadzu, Japan) equipped with an ESA $5011(\mathrm{E} 1=-175 ; \mathrm{E} 2=+250)$ electrochemical cell and a Coulochem III electrochemical detector (ESA, United States). The flow rate of the mobile phase was $1 \mathrm{~mL} / \mathrm{min}$. The results were processed on a PC using Multichrom 1.5 software (Ampersand, Russia). MAO and catechol-O-methyltransferase (COMT) are involved in the biodegradation of dopamine. Therefore, we used the metabolic ratio DOPAC/DA, which reflects MAO activity; HVA/DA, which reflects the COMT activity; and the total ratio (DOPAC + HVA)/DA ${ }^{76}$.

Immunohistochemical analysis. Fourteen days after the surgery, the mice were decapitated, and the brains were extracted. Specimens were fixed for 24 hours by immersion in $4 \%$ PFA solution, soaked in $30 \%$ sucrose and embedded in Tissue Teck O.S.T. medium. Twelve micrometer thick serial frontal sections of the midbrain in the region of the SNc were prepared utilizing a Sakura Tissue Tec Cryo3 cryotome. Prior to staining, heat epitope retrieval was performed in $0.1 \mathrm{M}$ citric buffer solution $(\mathrm{pH} 6.0)$ in a microwave oven in repeated cycles ( $600 \mathrm{~W}, 5$ minutes). A large water bath that contained vials with slides and a mercury thermometer was placed into a microwave oven. Heating was intermitted so the temperature stayed at $93-96^{\circ} \mathrm{C}$. After cooling, the slides were rinsed with PBS and left for 1 hour in PBS containing $0.1 \%$ Triton X-100. To reveal dopamine-producing neurons in the $\mathrm{SNc}$, slides were incubated with rabbit polyclonal antibodies against tyrosine hydroxylase (1:500 dilution) for 16 hours. Bound rabbit immunoglobulins were visualized by goat antibodies conjugated with CF488 fluorochrome. Primary and secondary antibodies were incubated at room temperature in a light-proof dampening chamber. Nuclei were counterstained with DAPI. All slides were coverslipped in Fluoroshield mounting medium. Imaging was carried out using a Nikon Eclipse fluorescence microscope equipped with a Nikon DS-Qi camera.

The density of $\mathrm{TH}$-positive $(\mathrm{TH}+)$ neurons with nuclei in the slice plane was counted at 40x magnification using ImageJ software (National Institute of Health). The count was performed in 3-6 slices of the SNc (rostral, medial and caudal regions) from each animal obtained under the same microscopy conditions, i.e., exposition time $800 \mathrm{~ms}$, gain 1.1. In each animal, cells from the ipsi- and contralateral sides with respect to 6-OHDA injection were counted in 5-7 fields of view $\left(0.044 \mathrm{~mm}^{2}\right)$, and the mean was calculated. The density of SNc neurons on the ipsilateral side was expressed as a percentage of the contralateral side.

Statistical analysis. To evaluate the type of experimental data distribution, D'Agostino-Pearson and Shapiro-Wilk tests were used. Because the data for DA content and latency to fall in the rotarod test did not fit a Gaussian distribution in the majority of groups, the Wilcoxon test and Kruskal-Wallis test with Dunn's post hoc test were used. ANOVA with the Holm-Sidak post hoc test was used to evaluate the statistical significance of the $\mathrm{TH}+$ neuron count. Linear coupling analysis of DA content in the striatum with the relative $\mathrm{TH}+$ neuron count or latency to fall in the rotarod test was performed using Spearman correlation analysis. Tabular data are presented as medians with lower and upper quartiles (Mdn (q25-75)). Data in histograms are presented as the median with the minimum and maximum (Mdn (min-max)) and the mean. Animals were classified using $\mathrm{k}$-means clustering by DA content in the striatum and latency to fall in the rotarod test as variables. The population was divided into two clusters. Statistical analysis of raw data and the visualization of obtained results were performed using GraphPad Prism version 8.0.1 for Windows, GraphPad Software, La Jolla California USA, www. graphpad.com and Statistica (StatSoft, Inc).

\section{Data availability}

The datasets analyzed in this study are available from the corresponding author upon reasonable request.

Received: 28 May 2019; Accepted: 28 October 2019;

Published online: 19 November 2019

\section{References}

1. Poewe, W. et al. Parkinson disease. Nature reviews. Disease primers 3, 17013, https://doi.org/10.1038/nrdp.2017.13 (2017).

2. Dorsey, E. R., Sherer, T., Okun, M. S. \& Bloem, B. R. The Emerging Evidence of the Parkinson Pandemic. J Parkinsons Dis 8, S3-S8, https://doi.org/10.3233/JPD-181474 (2018).

3. Schapira, A. H. Etiology and pathogenesis of Parkinson disease. Neurol Clin 27, 583-603, v, https://doi.org/10.1016/j.ncl.2009.04.004 (2009).

4. Coskun, P. et al. A mitochondrial etiology of Alzheimer and Parkinson disease. Biochim Biophys Acta 1820, 553-564, https://doi. org/10.1016/j.bbagen.2011.08.008 (2012).

5. Michel, P. P., Hirsch, E. C. \& Hunot, S. Understanding Dopaminergic Cell Death Pathways in Parkinson Disease. Neuron 90, 675-691, https://doi.org/10.1016/j.neuron.2016.03.038 (2016).

6. De Miranda, B. R. \& Greenamyre, J. T. In Oxidative Stress and Redox Signalling in Parkinson's Disease (eds Franco, R., Doorn, J. A. \& Rochet, J. C.) Ch. 1, 1-26 (Royal Society of Chemistry, 2017).

7. Connolly, B. S. \& Lang, A. E. Pharmacological treatment of Parkinson disease: a review. JAMA 311, 1670-1683, https://doi. org/10.1001/jama.2014.3654 (2014).

8. Peeters, M., Maloteaux, J. M. \& Hermans, E. Distinct effects of amantadine and memantine on dopaminergic transmission in the rat striatum. Neurosci Lett 343, 205-209 (2003).

9. Schmidt, H. R. et al. Crystal structure of the human sigmal receptor. Nature 532, 527-530, https://doi.org/10.1038/nature17391 (2016).

10. Nguyen, L., Lucke-Wold, B. P., Mookerjee, S., Kaushal, N. \& Matsumoto, R. R. Sigma-1 Receptors and Neurodegenerative Diseases: Towards a Hypothesis of Sigma-1 Receptors as Amplifiers of Neurodegeneration and Neuroprotection. Advances in experimental medicine and biology 964, 133-152, https://doi.org/10.1007/978-3-319-50174-1_10 (2017). 
11. Francardo, V. et al. Pharmacological stimulation of sigma-1 receptors has neurorestorative effects in experimental parkinsonism. Brain: a journal of neurology 137, 1998-2014, https://doi.org/10.1093/brain/awu107 (2014).

12. Hong, J., Wang, L., Zhang, T., Zhang, B. \& Chen, L. Sigma-1 receptor knockout increases alpha-synuclein aggregation and phosphorylation with loss of dopaminergic neurons in substantia nigra. Neurobiol Aging 59, 171-183, https://doi.org/10.1016/j. neurobiolaging.2017.08.007 (2017).

13. Francardo, V. et al. Pridopidine Induces Functional Neurorestoration Via the Sigma-1 Receptor in a Mouse Model of Parkinson's Disease. Neurotherapeutics. https://doi.org/10.1007/s13311-018-00699-9 (2019).

14. Hayashi, T. \& Su, T. P. Sigma-1 receptor chaperones at the ER-mitochondrion interface regulate $\mathrm{Ca}(2+)$ signaling and cell survival. Cell 131, 596-610, S0092-8674(07)01099-9 (2007).

15. Hayashi, T. et al. Regulation of sigma-1 receptors and endoplasmic reticulum chaperones in the brain of methamphetamine selfadministering rats. J Pharmacol Exp Ther 332, 1054-1063, https://doi.org/10.1124/jpet.109.159244 (2010).

16. Navarro, G. et al. Cocaine inhibits dopamine D2 receptor signaling via sigma-1-D2 receptor heteromers. PloS one 8, e61245, https:// doi.org/10.1371/journal.pone.0061245 (2013).

17. Schmidt, H. R., Betz, R. M., Dror, R. O. \& Kruse, A. C. Structural basis for sigma1 receptor ligand recognition. Nature structural \& molecular biology 25, 981-987, https://doi.org/10.1038/s41594-018-0137-2 (2018).

18. Su, T. P., Su, T. C., Nakamura, Y. \& Tsai, S. Y. The Sigma-1 Receptor as a Pluripotent Modulator in Living Systems. Trends in pharmacological sciences 37, 262-278, https://doi.org/10.1016/j.tips.2016.01.003 (2016).

19. Omura, T., Kaneko, M., Okuma, Y., Matsubara, K. \& Nomura, Y. Endoplasmic reticulum stress and Parkinson's disease: the role of HRD1 in averting apoptosis in neurodegenerative disease. Oxid Med Cell Longev 2013, 239854, https://doi.org/10.1155/2013/239854 (2013).

20. Mori, T., Hayashi, T., Hayashi, E. \& Su, T. P. Sigma-1 receptor chaperone at the ER-mitochondrion interface mediates the mitochondrion-ER-nucleus signaling for cellular survival. PloS one 8, e76941, https://doi.org/10.1371/journal.pone.0076941 (2013).

21. Natsvlishvili, N., Goguadze, N., Zhuravliova, E. \& Mikeladze, D. Sigma-1 receptor directly interacts with Rac1-GTPase in the brain mitochondria. BMC biochemistry 16, 11, https://doi.org/10.1186/s12858-015-0040-y (2015).

22. Mori, T., Hayashi, T. \& Su, T. P. Compromising sigma-1 receptors at the endoplasmic reticulum render cytotoxicity to physiologically relevant concentrations of dopamine in a nuclear factor-kappaB/Bcl-2-dependent mechanism: potential relevance to Parkinson's disease. J Pharmacol Exp Ther 341, 663-671, jpet.111.190868 (2012).

23. Nguyen, L. et al. Role of sigma-1 receptors in neurodegenerative diseases. Journal of pharmacological sciences 127, 17-29, https://doi. org/10.1016/j.jphs.2014.12.005 (2015)

24. Skuza, G. Pharmacology of sigma (sigma) receptor ligands from a behavioral perspective. Current pharmaceutical design 18, 863-874 (2012).

25. Gromek, K. A. et al. The oligomeric States of the purified sigma-1 receptor are stabilized by ligands. The Journal of biological chemistry 289, 20333-20344, https://doi.org/10.1074/jbc.M113.537993 (2014).

26. Chu, X. P. \& Xiong, Z. G. Physiological and pathological functions of acid-sensing ion channels in the central nervous system. Current drug targets 13, 263-271 (2012).

27. Tubert, C. et al. Decrease of a Current Mediated by Kv1.3 Channels Causes Striatal Cholinergic Interneuron Hyperexcitability in Experimental Parkinsonism. Cell reports 16, 2749-2762, https://doi.org/10.1016/j.celrep.2016.08.016 (2016).

28. Fordyce, C. B., Jagasia, R., Zhu, X. \& Schlichter, L. C. Microglia Kv1.3 channels contribute to their ability to kill neurons. The Journal of neuroscience: the official journal of the Society for Neuroscience 25, 7139-7149, https://doi.org/10.1523/JNEUROSCI.1251-05.2005 (2005).

29. Richardson, J. R. \& Hossain, M. M. Microglial ion channels as potential targets for neuroprotection in Parkinson's disease. Neural plasticity 2013, 587418, https://doi.org/10.1155/2013/587418 (2013).

30. Chao, R. Y., Cheng, C. H., Wu, S. N. \& Chen, P. C. Defective trafficking of Kv2.1 channels in MPTP-induced nigrostriatal degeneration. Journal of neurochemistry, https://doi.org/10.1111/jnc.14282 (2017).

31. Hallett, P. J. et al. Alterations of striatal NMDA receptor subunits associated with the development of dyskinesia in the MPTPlesioned primate model of Parkinson's disease. Neuropharmacology 48, 503-516, https://doi.org/10.1016/j.neuropharm.2004.11.008 (2005).

32. Hisahara, S. \& Shimohama, S. Dopamine receptors and Parkinson's disease. International journal of medicinal chemistry 2011, 403039, https://doi.org/10.1155/2011/403039 (2011).

33. Brotchie, J. M. CB1 cannabinoid receptor signalling in Parkinson's disease. Current opinion in pharmacology 3, 54-61 (2003).

34. Fenner, M. E., Achim, C. L. \& Fenner, B. M. Expression of full-length and truncated trkB in human striatum and substantia nigra neurons: implications for Parkinson's disease. Journal of molecular histology 45, 349-361, https://doi.org/10.1007/s10735-013-9562-z (2014).

35. Brimson, J. M., Safrany, S. T., Qassam, H. \& Tencomnao, T. Dipentylammonium Binds to the Sigma-1 Receptor and Protects Against Glutamate Toxicity, Attenuates Dopamine Toxicity and Potentiates Neurite Outgrowth in Various Cultured Cell Lines. Neurotox Res 34, 263-272, https://doi.org/10.1007/s12640-018-9883-5 (2018).

36. Hong, J. et al. Sigma-1 receptor deficiency reduces MPTP-induced parkinsonism and death of dopaminergic neurons. Cell death \& disease 6, e1832, https://doi.org/10.1038/cddis.2015.194 (2015).

37. Seredenin, S. B. et al. [The pharmacogenetic concept of the anxio-selective effect]. Vestn Ross Akad Med Nauk, 3-9 (1998).

38. Seredenin, S. B. \& Voronin, M. V. [Neuroreceptor mechanisms of the afobazole effect]. Eksp Klin Farmakol 72, 3-11 (2009).

39. Voronin, M. V. \& Kadnikov, I. A. Contribution of Sigma-1 receptor to cytoprotective effect of afobazole. Pharmacology research \& perspectives 4, e00273, https://doi.org/10.1002/prp2.273 (2016).

40. Zenina, T. A., Gavrish, I. V., Melkumyan, D. S., Seredenina, T. S. \& Seredenin, S. B. Neuroprotective properties of afobazol in vitro. Bull Exp Biol Med 140, 194-196 (2005).

41. Galaeva, I. P., Garibova, T. L., Voronina, T. A. \& Seredenin, S. B. Neuroprotective effects of afobazol in experimental cerebral hemorrhage. Bull Exp Biol Med 140, 535-537 (2005).

42. Kraineva, V. A. \& Seredenin, S. B. Neuroprotective properties of afobazole in repeated hemorrhagic stroke modeling in aged rats. Bull Exp Biol Med 149, 204-207 (2010).

43. Voronin, M. V., Kadnikov, I. A. \& Seredenin, S. B. Afobazole Restores the Dopamine Level in a 6-Hydroxydopamine Model of Parkinson's Disease. Neurochemical Journal 13, 49-56, https://doi.org/10.1134/S1819712419010185 (2019).

44. Goes, A. T. R. et al. Protective role of chrysin on 6-hydroxydopamine-induced neurodegeneration a mouse model of Parkinson's disease: Involvement of neuroinflammation and neurotrophins. Chem Biol Interact 279, 111-120, https://doi.org/10.1016/j. cbi.2017.10.019 (2018).

45. Alvarez-Fischer, D. et al. Characterization of the striatal 6-OHDA model of Parkinson's disease in wild type and alpha-synucleindeleted mice. Exp Neurol 210, 182-193, https://doi.org/10.1016/j.expneurol.2007.10.012 (2008).

46. Aguiar, L. M. et al. Neuroprotective effects of caffeine in the model of 6-hydroxydopamine lesion in rats. Pharmacology, biochemistry, and behavior 84, 415-419, https://doi.org/10.1016/j.pbb.2006.05.027 (2006).

47. Chan, H. H., Kumar, S. \& Zhuo, L. Neuroprotective and behavioural assessments of an imidazolium compound (DBZIM) in a rat model of Parkinson's disease induced by 6-OHDA. European journal of pharmacology 715, 405-413, https://doi.org/10.1016/j. ejphar.2013.04.023 (2013). 
48. Muralikrishnan, D. \& Mohanakumar, K. P. Neuroprotection by bromocriptine against 1-methyl-4-phenyl-1,2,3,6tetrahydropyridine-induced neurotoxicity in mice. FASEB J 12, 905-912 (1998).

49. Voronin, M. V., Aksenova, L. N., Buneena, O. A. \& Medvedev, A. E. Effect of afobazole on mitochondrial monoamine oxidase A activity in vitro. Bull Exp Biol Med 148, 23-25 (2009).

50. Kadnikov, I. A., Voronin, M. V. \& Seredenin, S. B. Effect of Afobazole on Activity of Quinone Reductase 2. Pharm Chem J+ 47, 514-516, https://doi.org/10.1007/s11094-014-0993-y (2014).

51. Riederer, P. \& Laux, G. MAO-inhibitors in Parkinson's Disease. Exp Neurobiol 20, 1-17, https://doi.org/10.5607/en.2011.20.1.1 (2011).

52. Berretta, N. et al. Acute effects of 6-hydroxydopamine on dopaminergic neurons of the rat substantia nigra pars compacta in vitro. Neurotoxicology 26, 869-881, https://doi.org/10.1016/j.neuro.2005.01.014 (2005).

53. Cuevas, J., Behensky, A., Deng, W. \& Katnik, C. Afobazole modulates neuronal response to ischemia and acidosis via activation of sigma-1 receptors. J Pharmacol Exp Ther 339, 152-160, jpet.111.182774 (2011).

54. Marinova-Mutafchieva, L. et al. Relationship between microglial activation and dopaminergic neuronal loss in the substantia nigra: a time course study in a 6-hydroxydopamine model of Parkinson's disease. Journal of neurochemistry 110, 966-975, https://doi. org/10.1111/j.1471-4159.2009.06189.x (2009).

55. Stott, S. R. \& Barker, R. A. Time course of dopamine neuron loss and glial response in the 6-OHDA striatal mouse model of Parkinson's disease. The European journal of neuroscience 39, 1042-1056, https://doi.org/10.1111/ejn.12459 (2014).

56. Cuevas, J., Rodriguez, A., Behensky, A. \& Katnik, C. Afobazole modulates microglial function via activation of both sigma-1 and sigma-2 receptors. J Pharmacol Exp Ther 339, 161-172, jpet.111.182816 (2011).

57. Behensky, A. A. et al. Afobazole activation of sigma-1 receptors modulates neuronal responses to amyloid-beta25-35. J Pharmacol Exp Ther 347, 468-477, https://doi.org/10.1124/jpet.113.208330 (2013).

58. Hanner, M. et al. Purification, molecular cloning, and expression of the mammalian sigma1-binding site. Proceedings of the National Academy of Sciences of the United States of America 93, 8072-8077 (1996).

59. Alon, A. et al. Identification of the gene that codes for the sigma2 receptor. Proceedings of the National Academy of Sciences of the United States of America 114, 7160-7165, https://doi.org/10.1073/pnas.1705154114 (2017).

60. Zeng, C. et al. TMEM97 and PGRMC1 do not mediate sigma-2 ligand-induced cell death. Cell Death Discov 5, 58, https://doi. org/10.1038/s41420-019-0141-2 (2019).

61. Riad, A. et al. Sigma-2 Receptor/TMEM97 and PGRMC-1 Increase the Rate of Internalization of LDL by LDL Receptor through the Formation of a Ternary Complex. Scientific reports 8, 16845, 10.1038/s41598-018-35430-3 (2018).

62. Yang, K., Wang, C. \& Sun, T. The Roles of Intracellular Chaperone Proteins, Sigma Receptors, in Parkinson's Disease (PD) and Major Depressive Disorder (MDD). Frontiers in pharmacology 10, 528, https://doi.org/10.3389/fphar.2019.00528 (2019).

63. Moreno, J. A. \& Tiffany-Castiglioni, E. The chaperone Grp78 in protein folding disorders of the nervous system. Neurochemical research 40, 329-335, https://doi.org/10.1007/s11064-014-1405-0 (2015).

64. Ortega-Roldan, J. L., Ossa, F. \& Schnell, J. R. Characterization of the human sigma-1 receptor chaperone domain structure and binding immunoglobulin protein (BiP) interactions. The Journal of biological chemistry 288, 21448-21457, https://doi.org/10.1074/ jbc.M113.450379 (2013).

65. Miki, Y., Tanji, K., Mori, F. \& Wakabayashi, K. Sigma-1 receptor is involved in degradation of intranuclear inclusions in a cellular model of Huntington's disease. Neurobiol Dis 74, 25-31, https://doi.org/10.1016/j.nbd.2014.11.005 (2015).

66. Hong, L., Huang, H. C. \& Jiang, Z. F. Relationship between amyloid-beta and the ubiquitin-proteasome system in Alzheimer's disease. Neurol Res 36, 276-282, https://doi.org/10.1179/1743132813Y.0000000288 (2014).

67. Lai, A. Y. \& McLaurin, J. Mechanisms of amyloid-Beta Peptide uptake by neurons: the role of lipid rafts and lipid raft-associated proteins. Int J Alzheimers Dis 2011, 548380, https://doi.org/10.4061/2011/548380 (2010).

68. Jin, S. et al. Amyloid-beta(1-42) Aggregation Initiates Its Cellular Uptake and Cytotoxicity. The Journal of biological chemistry 291, 19590-19606, https://doi.org/10.1074/jbc.M115.691840 (2016)

69. LaVoie, M. J. \& Hastings, T. G. Dopamine quinone formation and protein modification associated with the striatal neurotoxicity of methamphetamine: evidence against a role for extracellular dopamine. The Journal of neuroscience: the official journal of the Society for Neuroscience 19, 1484-1491 (1999).

70. Berman, S. B. \& Hastings, T. G. Dopamine oxidation alters mitochondrial respiration and induces permeability transition in brain mitochondria: implications for Parkinson's disease. Journal of neurochemistry 73, 1127-1137 (1999).

71. Blum, D. et al. Molecular pathways involved in the neurotoxicity of 6-OHDA, dopamine and MPTP: contribution to the apoptotic theory in Parkinson's disease. Progress in neurobiology 65, 135-172 (2001).

72. Dias, V., Junn, E. \& Mouradian, M. M. The role of oxidative stress in Parkinson's disease. J Parkinsons Dis 3, 461-491, https://doi. org/10.3233/JPD-130230 (2013).

73. GOST 33215-2014. Guidelines for accommodation and care of animals. Environment, housing and management. Interstate Counsil for Standartization, Metrology and Certification, http://protect.gost.ru/document.aspx?control=7\&id=202494 (2016).

74. National Research Council (U.S.). Committee for the Update of the Guide for the Care and Use of Laboratory Animals., Institute for Laboratory Animal Research (U.S.) \& National Academies Press (U.S.). xxv, 220 p (National Academies Press, Washington, D.C., 2011).

75. Flecknell, P. In Laboratory Animal Anaesthesia Ch. 5, 193-256 (Academic Press, 2015).

76. Roffler-Tarlov, S., Sharman, D. F. \& Tegerdine, P. 3,4-dihydroxyphenylacetic acid and 4-hydroxy-3-methoxyphenylacetic acid in the mouse striatum: a reflection of intra- and extra-neuronal metabolism of dopamine? British journal of pharmacology 42, 343-351 (1971).

\section{Acknowledgements}

The research was conducted within the frameworks of the government contracts of the Ministry of Science and Higher Education of the Russian Federation (Project 0521-2019-0002).

\section{Author contributions}

M.V., I.K., D.V. and S.S. designed the experiment, analyzed the data, and wrote and reviewed the manuscript. I.K. and D.V. performed the experiments.

\section{Competing interests}

The authors declare no competing interests.

\section{Additional information}

Supplementary information is available for this paper at https://doi.org/10.1038/s41598-019-53413-w.

Correspondence and requests for materials should be addressed to I.A.K. 
Reprints and permissions information is available at www.nature.com/reprints.

Publisher's note Springer Nature remains neutral with regard to jurisdictional claims in published maps and institutional affiliations.

(c) (i) Open Access This article is licensed under a Creative Commons Attribution 4.0 International License, which permits use, sharing, adaptation, distribution and reproduction in any medium or format, as long as you give appropriate credit to the original author(s) and the source, provide a link to the Creative Commons license, and indicate if changes were made. The images or other third party material in this article are included in the article's Creative Commons license, unless indicated otherwise in a credit line to the material. If material is not included in the article's Creative Commons license and your intended use is not permitted by statutory regulation or exceeds the permitted use, you will need to obtain permission directly from the copyright holder. To view a copy of this license, visit http://creativecommons.org/licenses/by/4.0/.

(C) The Author(s) 2019 